\title{
PREDICTORS OF DIFFICULT AIRWAY MANAGEMENT IN THYROID SURGERY: A FIVE-YEAR OBSERVATIONAL SINGLE-CENTER PROSPECTIVE STUDY
}

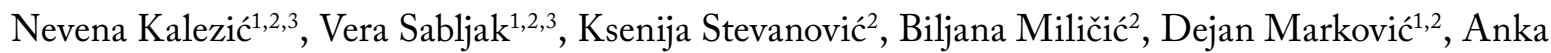 \\ Tošković, ${ }^{2,3}$, Marina Stojanović ${ }^{2}$ and Vladan Živaljević ${ }^{1,3}$
}

${ }^{1}$ School of Medicine, University of Belgrade; ${ }^{2}$ Center for Anesthesiology and Resuscitation, ${ }^{3}$ Center for Endocrine Surgery, Clinical Center of Serbia, Belgrade, Serbia

\begin{abstract}
SUMMARY - Difficult tracheal intubation (DI) is more common in thyroid than in other surgical branches due to thyromegaly. Proper preoperative airway evaluation is necessary in order to reduce the potential numerous complications. The study examined the incidence of DI in thyroid surgery and the influence of tracheal dislocation and other risk factors on DI. A prospective study was conducted on 2379 patients who underwent thyroidectomy at the Center for Endocrine Surgery, Clinical Center of Serbia, from 2007 to 2012. Patients were divided into groups with ( $\mathrm{n}=162$ ) and without DI ( $\mathrm{n}=2217)$. Besides tracheal dislocation, another 13 risk factors contained in 13 screening tests and three additional factors of gender, age and diagnosis were defined. The incidence of DI in our study was $6.81 \%$. The presence of tracheal dislocation was statistically significant, but not an independent predictor of DI. The diagnosis, large circumference and small neck length, previous DI, recessive mandible, tooth characteristics and oral anomalies were the most significant and independent predictors of DI. Neck circumference and small neck length had highest sensitivity. Previous DI had highest specificity. Thyromegaly, if causing tracheal dislocation and/or stenosis, represents a significant DI predictor, not individually, but in combination with other factors.
\end{abstract}

Key Words: Airway Management; Intubation, Intratracheal - Methods; Thyroid Diseases - Surgery; Tracheal Dislocation

\section{Introduction}

It is well known that the causes of difficult intubation (DI) of the trachea can be congenital and acquired anomalies, especially anomalies of the head and neck. Among the acquired causes, endocrine disorders including thyroid gland diseases occupy an important place ${ }^{1,2}$. Thyroid gland diseases often are associated with thyromegaly, which, on the one hand, leads to increased neck size, especially its circum-

Correspondence to: Prof. Nevena Kalezic, $M D, P b D$, Center for Endocrine Surgery, Clinical Center of Serbia, Pasterova 2, 11000 Belgrade, Serbia

E-mail: casopis.anestezija@gmail.com

Received February 27, 2015, accepted September 10, 2015 ference, which is a known predictor of DI in other branches of surgery. On the other hand, enlarged thyroid can compress the trachea and lead to its deviation (dislocation) and/or stenosis. Although trachea dislocation (deviation of the trachea from the midline by more than $1 \mathrm{~cm}$ ) has always been associated with DI, a small number of published papers confirm this assertion. In more severe cases, compression of the trachea may lead to its stenosis, if the lumen narrowing is greater than $30 \%$. Severe tracheal stenosis (over $70 \%$ of its normal lumen width) results in progressive steady-state dyspnea and such patients are at greatest risk of various complications during airway management, including total airway obstruction ${ }^{3,4}$. The existence of tracheal dislocation and stenosis at the same time certainly represents the most difficult clinical 
scenario. Unfortunately, this scenario is often seen precisely in thyroid surgery and requires vast knowledge and experience of the anesthesiologist.

Numerous studies showed a high incidence of DI in thyroid surgery, ranging from $5.3 \%$ to $16.5 \% \%^{5-7}$. However, we still cannot certainly claim which methods of preoperative evaluation of the airway have the highest predictive value in assessing possible DI because there are not enough well-documented studies.

The aim of our study was to investigate the incidence of DI in thyroid surgery, the influence of tracheal dislocation and/or stenosis on DI, and to analyze other risk factors for DI that were part of the scoring scale created in our Center and adapted to our patients.

\section{Patients and Methods}

We conducted a prospective study on $2379 \mathrm{pa}^{-}$ tients undergoing surgery of the thyroid gland at the Center for Endocrine Surgery, Clinical Center of Serbia, during the period from 2007 to 2012. Patients were divided into groups with DI (162 patients) and without DI (2217 patients). In addition to tracheal dislocation/stenosis, we defined another 13 risk factors that were part of 13 screening tests used in the prediction of difficult intubation and three additional factors of gender, age and diagnosis: nodular goiter, multinodular goiter, toxic adenoma, hyperthyroidism, papillary cancer, medullary cancer, anaplastic cancer, postoperative hematoma, Hashimoto thyroiditis, recurrent goiter, struma permagna, retrosternal goiter and multinodular toxic goiter.

Difficult intubation was defined as tracheal intubation without visualization of the glottis during laryngoscopy (grade III or IV according to Cormac-Lehane laryngoscopy classification) ${ }^{8}$. Several maneuvers if applied during intubation were taken into account (external pressure on the larynx, use of intubation stylet). Also, the number of attempts and duration of intubation were taken into account, which is consistent with the criteria of the American Society of Anesthesiologists ${ }^{9}$. Intubation was performed by four experienced anesthesiologists and anesthesiology residents.

\section{Table 1. Potential predictors of difficult intubation (DI)}

\begin{tabular}{|c|c|c|c|}
\hline Potential predictors of DI & $\begin{array}{l}\text { No risk } \\
0 \text { points }\end{array}$ & $\begin{array}{c}\text { Moderate risk } 1 \\
\text { point }\end{array}$ & $\begin{array}{l}\text { High risk } \\
2 \text { points }\end{array}$ \\
\hline History of previous DI & No/not known & - & Positive \\
\hline $\begin{array}{l}\text { Tracheal dislocation and/or stenosis } \\
\text { (according to neck and chest } \mathrm{x} \text {-ray) }\end{array}$ & No & Moderate & Significant \\
\hline $\begin{array}{l}\text { Larynx/vocal cords/airway } \\
\text { (according to ENT examination) }\end{array}$ & No & Paresis/paralysis & Dislocation \\
\hline Anatomic deformities of bones and joints & No & - & \\
\hline Retrognathic ('recessive') mandible & No & - & \\
\hline Size, layout and position of teeth (incisors) & Normal & Long & Asymmetric \\
\hline Oral anomalies (small mouth, macroglossia, tumors) & No & - & Macroglossia, tumor \\
\hline Body mass index & $20-25 \mathrm{~kg} / \mathrm{m}^{2}$ & $25-30 \mathrm{~kg} / \mathrm{m}^{2}$ & $>30 \mathrm{~kg} / \mathrm{m}^{2}$ \\
\hline Degree of neck mobility (maximum extension) & $>90^{\circ}$ & $80-90^{\circ}$ & $<80^{\circ}$ \\
\hline $\begin{array}{l}\text { Thyromental distance } \\
\text { (distance from the tip of the chin to Adam's apple) }\end{array}$ & $>6.5 \mathrm{~cm}$ & $6-6.5 \mathrm{~cm}$ & $<6 \mathrm{~cm}$ \\
\hline $\begin{array}{l}\text { Interincisor gap (distance upper/lower incisors) } \\
\text { M } \\
\text { F }\end{array}$ & $\begin{array}{l}>5 \mathrm{~cm} \\
>4 \mathrm{~cm}\end{array}$ & $\begin{array}{l}4-4.5 \mathrm{~cm} \\
3.5-4 \mathrm{~cm}\end{array}$ & $<3.5 \mathrm{~cm}$ \\
\hline Maximum protrusion of the mandible over the maxilla & $>0 \mathrm{~cm}$ & $=0 \mathrm{~cm}$ & $<0 \mathrm{~cm}$ \\
\hline Neck circumference and length & Normal & Short or wide & Short and wide \\
\hline Mallampati score & $\mathrm{I}+\mathrm{II}$ & III & IV \\
\hline
\end{tabular}


In order to predict DI, 14 parameters, i.e. potential risk factors were used and scored with $0-2$ points ( 0 no risk, 1 moderate risk, and 2 high risk), with maximum score of 28. A total score higher than 5 was considered as a predictor of DI occurrence (Table 1 ). Three additional potential risk factors of gender, age and surgical diagnosis were included.

\section{Statistics}

Data collected through preoperative evaluation of the airway were entered into the electronic database. Statistical analysis was performed with SPSS 18.0 for Windows (SPSS Inc., Chicago, IL, USA). The methods of descriptive and analytical statistics evaluated the specificity and sensitivity of each risk factor. Data were presented as mean, standard deviation and median. For comparison of characteristics between the study groups we used Pearson's $\chi^{2}$-test (contingency tables). Selection of tests for the analysis of numerical variables depended on the nature of their distribution, which was evaluated using Kolmogorov-Smirnov test. To test for differences between patients with and without DI with nonparametric data, Mann Whitney U test was used. Logistic regression was used to determine differences between the groups of patients with and without DI, as well as to determine odds ratio for the observed risk factors and the probability of the occurrence of DI. The level of statistical significance was set at $\mathrm{p}<0.05$.

\section{Results}

The incidence of DI in our study was $6.81 \%$. Gender, age and surgical diagnosis were significantly different between the two study groups (Table 2). All 14 potential risk factors/tests for assessing the airway were statistically significantly different between the two patient groups (Table 3). Since the univariate

Table 2. General characteristics of patients with and without diffcult intubation

\begin{tabular}{|c|c|c|c|c|}
\hline & & \multicolumn{2}{|c|}{ Difficult intubation } & \multirow{2}{*}{ Significance } \\
\hline & & Yes & No & \\
\hline \multicolumn{2}{|c|}{ Number of patients (n) } & 162 & 2216 & \\
\hline \multicolumn{2}{|c|}{$\begin{array}{l}\text { Age } \\
(\text { Mean } \pm S D(\text { Med, min-max)) }\end{array}$} & $\begin{array}{c}54.10 \pm 11.81 \\
(55 ; 19-82) \\
\end{array}$ & $\begin{array}{c}50.77 \pm 14.41 \\
(52.50 ; 20-90)\end{array}$ & ${ }^{\mathrm{a}} \mathrm{p}=0.006^{*}$ \\
\hline \multirow{2}{*}{$\begin{array}{l}\text { Gender, } \\
\mathrm{n}(\%)\end{array}$} & Male & $32(19.8 \%)$ & $307(13.8 \%)$ & \multirow{2}{*}{${ }^{\mathrm{b}} \mathrm{p}=0.038^{*}$} \\
\hline & Female & $130(80.2 \%)$ & $1910(86.2 \%)$ & \\
\hline \multirow{15}{*}{$\begin{array}{l}\text { Diagnosis, } \\
\mathrm{n}(\%)\end{array}$} & Nodular goiter & $14(8.6 \%)$ & $488(22.0 \%)$ & \multirow{15}{*}{${ }^{b} p=0.000^{*}$} \\
\hline & Multinodular goiter & $63(38.9 \%)$ & $788(35.5 \%)$ & \\
\hline & Toxic adenoma & $1(0.6 \%)$ & $87(3.9 \%)$ & \\
\hline & Hyperthyroidism & $25(15.4 \%)$ & $385(17.4 \%)$ & \\
\hline & Papillary cancer & $8(4.9 \%)$ & $125(5.6 \%)$ & \\
\hline & Medullary cancer & $2(1.2 \%)$ & $80(3.6 \%)$ & \\
\hline & Anaplastic cancer & $1(0.6 \%)$ & $11(0.5 \%)$ & \\
\hline & Postoperative hematoma & $20(12.3 \%)$ & $0(0 \%)$ & \\
\hline & Hashimoto thyroiditis & $4(2.5 \%)$ & $64(2.9 \%)$ & \\
\hline & Recurrent goiter & $3(1.9 \%)$ & $88(4.0 \%)$ & \\
\hline & Follicular carcinoma & $0(0 \%)$ & $11(0.5 \%)$ & \\
\hline & Struma permagna & $7(4.3 \%)$ & $20(0.9 \%)$ & \\
\hline & Retrosternal goiter & $6(3.7 \%)$ & $20(0.9 \%)$ & \\
\hline & Multinodular toxic goiter & $8(4.9 \%)$ & $38(1.7 \%)$ & \\
\hline & Thyroid cyst & $0(0 \%)$ & $12(0.5 \%)$ & \\
\hline
\end{tabular}

*statistically significant; ${ }^{\mathrm{a} M a n n}$ Whitney U-test; ${ }^{\mathrm{b}} \chi^{2}$-test 
Table 3. Predictive value of tests - parameters used to predict difficult intubation (DI)

\begin{tabular}{|c|c|c|c|c|}
\hline & \multicolumn{2}{|c|}{ Difficult intubation } & \multirow{2}{*}{ Significance } \\
\hline & & Yes & No & \\
\hline \multirow{2}{*}{ History of previous DI } & No/noUnavailable & $148(91.4 \%)$ & $2206(99.5 \%)$ & \multirow{2}{*}{${ }^{\mathrm{b}} \mathrm{p}=0.000^{*}$} \\
\hline & Positive & $14(8.6 \%)$ & $11(0.5 \%)$ & \\
\hline \multirow{3}{*}{$\begin{array}{l}\text { Dislocation and/or stenosis of } \\
\text { the trachea (according to neck } \\
\text { and chest } \mathrm{x} \text {-ray) }\end{array}$} & No & $50(30.9 \%)$ & $1114(50.2 \%)$ & \multirow{3}{*}{${ }^{b} \mathrm{p}=0.000^{*}$} \\
\hline & Moderate & $75(46.3 \%)$ & $918(41.4 \%)$ & \\
\hline & Significant & $37(22.8 \%)$ & $185(8.3 \%)$ & \\
\hline \multirow{3}{*}{$\begin{array}{l}\text { Larynx/vocal cords/ } \\
\text { airway (according to ENT } \\
\text { examination) }\end{array}$} & No & $142(87.6 \%)$ & $2104(94.9 \%)$ & \multirow{3}{*}{${ }^{b} \mathrm{p}=0.000^{*}$} \\
\hline & Paresis/paralysis & $15(9.3 \%)$ & $95(4.3 \%)$ & \\
\hline & Dislocation & $5(3.1 \%)$ & $17(0.8 \%)$ & \\
\hline \multirow{3}{*}{$\begin{array}{l}\text { Anatomic deformities of } \\
\text { bones and joints }\end{array}$} & No & $132(81.5 \%)$ & $1995(90.0 \%)$ & \multirow{3}{*}{${ }^{b} \mathrm{p}=0.001^{*}$} \\
\hline & Moderate & $24(14.8 \%)$ & $196(8.8 \%)$ & \\
\hline & Significant & $6(3.7 \%)$ & $26(1.2 \%)$ & \\
\hline \multirow{3}{*}{$\begin{array}{l}\text { Retrognathic ('recessive') } \\
\text { mandible }\end{array}$} & No & $116(71.6 \%)$ & $2012(90.8 \%)$ & \multirow{3}{*}{${ }^{b} \mathrm{p}=0.000^{*}$} \\
\hline & Moderate & $25(15.4 \%)$ & $162(7.3 \%)$ & \\
\hline & Significant & $21(13.0 \%)$ & $43(1.9 \%)$ & \\
\hline \multirow{3}{*}{$\begin{array}{l}\text { Size, layout and position of } \\
\text { teeth (incisors) }\end{array}$} & Normal & $113(69.8 \%)$ & $1771(79.9 \%)$ & \multirow{3}{*}{${ }^{b} \mathrm{p}=0.000^{*}$} \\
\hline & Long & $33(20.4 \%)$ & $359(16.2 \%)$ & \\
\hline & Asymmetric & $16(9.9 \%)$ & $87(3.9 \%)$ & \\
\hline \multirow{3}{*}{$\begin{array}{l}\text { Oral anomalies (small mouth, } \\
\text { macroglossia, tumors) }\end{array}$} & No & $99(61.1 \%)$ & $1820(82.1 \%)$ & \multirow{3}{*}{${ }^{b} \mathrm{p}=0.000^{*}$} \\
\hline & Small mouth & $60(37.0 \%)$ & $379(17.1 \%)$ & \\
\hline & Macroglossia, tumors & $3(1.9 \%)$ & $17(0.8 \%)$ & \\
\hline \multirow{3}{*}{ Body mass index } & $<25$ & $39(24.1 \%)$ & $1057(47.7 \%)$ & \multirow{3}{*}{${ }^{b} \mathrm{p}=0.000^{*}$} \\
\hline & $25-30$ & $71(43.8 \%)$ & $806(36.4 \%)$ & \\
\hline & $>30$ & $52(32.1 \%)$ & $354(16.0 \%)$ & \\
\hline \multirow{3}{*}{$\begin{array}{l}\text { Degree of neck mobility } \\
\text { (maximum extension) }\end{array}$} & $>90^{\circ}$ & $59(36.4 \%)$ & $1319(59.5 \%)$ & \multirow{3}{*}{${ }^{b} \mathrm{p}=0.000^{*}$} \\
\hline & $80-90^{\circ}$ & $82(50.6 \%)$ & $800(36.1 \%)$ & \\
\hline & $<80^{\circ}$ & $21(13.0 \%)$ & $98(4.4 \%)$ & \\
\hline \multirow{3}{*}{$\begin{array}{l}\text { Thyromental distance (tip } \\
\text { of the chin-Adam's apple } \\
\text { distance) }\end{array}$} & $>6.5 \mathrm{~cm}$ & $72(44.4 \%)$ & $1475(66.5 \%)$ & \multirow{3}{*}{${ }^{\mathrm{b}} \mathrm{p}=0.000^{*}$} \\
\hline & $6.5-6 \mathrm{~cm}$ & $75(46.3 \%)$ & $707(31.9 \%)$ & \\
\hline & $<6 \mathrm{~cm}$ & $15(9.3 \%)$ & $35(1.6 \%)$ & \\
\hline \multirow{3}{*}{$\begin{array}{l}\text { Interincisor gap (upper/lower } \\
\text { incisors distance) }\end{array}$} & $\begin{array}{l}\mathrm{M}>5 \mathrm{~cm} \\
\mathrm{~F}>4 \mathrm{~cm}\end{array}$ & $108(66.7 \%)$ & $1841(83.0 \%)$ & \multirow{3}{*}{${ }^{\mathrm{b}} \mathrm{p}=0.000^{*}$} \\
\hline & $\begin{array}{l}\text { M } 4-4.5 \mathrm{~cm} \\
\text { F } 3.5-4 \mathrm{~cm}\end{array}$ & $44(27.1 \%)$ & $364(16.4 \%)$ & \\
\hline & $<3.5 \mathrm{~cm}$ & $10(6.2 \%)$ & $12(0.5 \%)$ & \\
\hline \multirow{3}{*}{$\begin{array}{l}\text { Maximum protrusion of the } \\
\text { mandible over the maxilla }\end{array}$} & $>0 \mathrm{~cm}$ & $134(82.7 \%)$ & $1982(89.4 \%)$ & \\
\hline & $=0 \mathrm{~cm}$ & $27(16.7 \%)$ & $221(10.0 \%)$ & ${ }^{\mathrm{b}} \mathrm{p}=0.027^{*}$ \\
\hline & $<0 \mathrm{~cm}$ & $1(0.6 \%)$ & $14(0.6 \%)$ & \\
\hline & Normal & $62(38.3 \%)$ & $1578(71.2 \%)$ & \\
\hline $\begin{array}{l}\text { leck circumference and } \\
\text { length }\end{array}$ & Short or wide & $47(29.0 \%)$ & $503(22.7 \%)$ & ${ }^{b} p=0.000^{*}$ \\
\hline & Short and wide & $53(32.7 \%)$ & 136 (6.1\%) & \\
\hline & $\mathrm{I}+\mathrm{II}$ & $94(58.0 \%)$ & $1667(75.2 \%)$ & \\
\hline Mallampati score & III & $45(27.8 \%)$ & 414 (18.7\%) & ${ }^{b} p=0.000^{*}$ \\
\hline & IV & $23(14.2 \%)$ & $136(6.1 \%)$ & \\
\hline
\end{tabular}

*statistically significant; ${ }^{b} \chi^{2}$-test 
logistic regression analysis showed statistical significance for all 14 tests, three additional variables that were examined (gender, age and surgical diagnosis) and overall maximum value risk score $(\mathrm{R}>5)$, multivariate logistic regression analysis was performed, which showed that thyroid gland disease, previous DI, recessed (retrognathic) mandible, size, appearance and position of teeth, oral anomalies, and neck circumference and length were the strongest predictors of DI (Table 4).

The highest sensitivity was recorded for neck circumference and length, and highest specificity for positive history of previous DI (Fig. 1).

The number of attempts of intubation, duration and method of intubation are shown in Table 5. The prevalence of subjects with DI methods (using standard Macintosh blade or fiber optic) was also statistically significantly different $(\mathrm{p}<0.001)$.

\section{Discussion}

We analyzed 2379 patients undergoing elective surgical treatment of the thyroid. The incidence of DI was $6.81 \%$. In our previous study ${ }^{10}$ on $2000 \mathrm{pa}^{-}$ tients undergoing thyroid surgery, the incidence was 5.5\%. A similar incidence (5.3\%) was demonstrated in a study by Bouaggad et al. ${ }^{5}$. The study by Adnet $e t$ al. ${ }^{11}$ showed the incidence of DI of $8 \%$, and the study by Ammatei et al. of $11.1 \%{ }^{6}$. Shah and Gupta in their recent study showed the incidence of DI in thyroid

Table 4. Univariate and multivariate logistic regression analysis of the impact of observed factors on the occurrence of difficult intubation (DI)

\begin{tabular}{l|c|c|c|c}
\hline \multirow{2}{*}{ Risk factor } & \multicolumn{2}{|c|}{ Univariate } & \multicolumn{2}{c}{ Multivariate } \\
\cline { 2 - 5 } & RR (95\%CI) & Significance & RR (95\% CI) & Significance \\
\hline Gender & $1.531(1.021-2.296)$ & $\mathrm{p}=0.039^{*}$ & $1.003(0.989-1.018)$ & $\mathrm{p}=0.665$ \\
\hline Age & $0.983(0.972-0.995)$ & $\mathrm{p}=0.004^{*}$ & $1.192(0.699-2.031)$ & $\mathrm{p}=0.519$ \\
\hline Thyroid disease & $0.935(0.913-0.957)$ & $\mathrm{p}=0.000^{*}$ & $0.946(0.921-0.972)$ & $\mathrm{p}=0.000^{*}$ \\
\hline History of previous DI & $0.230(0.153-0.344)$ & $\mathrm{p}=0.000^{*}$ & $0,403(0.221-0.732)$ & $\mathrm{p}=0.003^{*}$ \\
\hline $\begin{array}{l}\text { Dislocation and/or stenosis of } \\
\text { the trachea }\end{array}$ & $0.481(0.382-0.606)$ & $\mathrm{p}=0.000^{*}$ & $0.743(0.505-1.093)$ & $\mathrm{p}=0.132$ \\
\hline Larynx/vocal cords/airway & $0.456(0.310-0.671)$ & $\mathrm{p}=0.000^{*}$ & $0.856(0.481-1.523)$ & $\mathrm{p}=0.596$ \\
\hline $\begin{array}{l}\text { Anatomic deformities of bones } \\
\text { and joints }\end{array}$ & $0.538(0.385-0.751)$ & $\mathrm{p}=0.000^{*}$ & $0.834(0.501-1.388)$ & $\mathrm{p}=0.485$ \\
\hline $\begin{array}{l}\text { Retrognathic ('recessive') } \\
\text { mandible }\end{array}$ & $0.351(0.273-0.451)$ & $\mathrm{p}=0.000^{*}$ & $0.420(0.279-0.634)$ & $\mathrm{p}=0.000^{*}$ \\
\hline $\begin{array}{l}\text { Size, layout and position of teeth } \\
\text { (incisors) }\end{array}$ & $0.620(0.482-0.798)$ & $\mathrm{p}=0.000^{*}$ & $0.661(0.441-0.992)$ & $\mathrm{p}=0.046^{*}$ \\
\hline $\begin{array}{l}\text { Oral anomalies (small mouth, } \\
\text { macroglossia, tumors) }\end{array}$ & $0.388(0.288-0.524)$ & $\mathrm{p}=0.000^{*}$ & $0.596(0.371-0.958)$ & $\mathrm{p}=0.033^{*}$ \\
\hline Body mass index & $0.505(0.409-0.622)$ & $\mathrm{p}=0.000^{*}$ & $0.967(0.622-1.503)$ & $\mathrm{p}=0.881$ \\
\hline Degree of neck mobility & $0.451(0.353-0.575)$ & $\mathrm{p}=0.000^{*}$ & $0.678(0.448-1.026)$ & $\mathrm{p}=0.066$ \\
\hline $\begin{array}{l}\text { Thyromental distance } \\
\text { Interincisor gap }\end{array}$ & $0.395(0.301-0.517)$ & $\mathrm{p}=0.000^{*}$ & $0.810(0.525-1.250)$ & $\mathrm{p}=0.341$ \\
\hline $\begin{array}{l}\text { Protrusion of the mandible over } \\
\text { the maxilla }\end{array}$ & $0.387(0.287-0.521)$ & $\mathrm{p}=0.000^{*}$ & $0.747(0.455-1.226)$ & $\mathrm{p}=0.249$ \\
\hline \begin{tabular}{l} 
Neck circumference and length \\
\hline Mallampati score
\end{tabular} & $0.324(0.263-0.399)$ & $\mathrm{p}=0.000^{*}$ & $0.562(0.378-0.835)$ & $\mathrm{p}=0.004^{*}$ \\
\hline Maximum score & $0.704(0.667-0.722-0.920)$ & $\mathrm{p}=0.017^{*}$ & $0.793(0.468-1.342)$ & $\mathrm{p}=0.387$ \\
\hline
\end{tabular}

*statistically significant; ${ }^{*} \mathrm{RR}=$ relative risk 


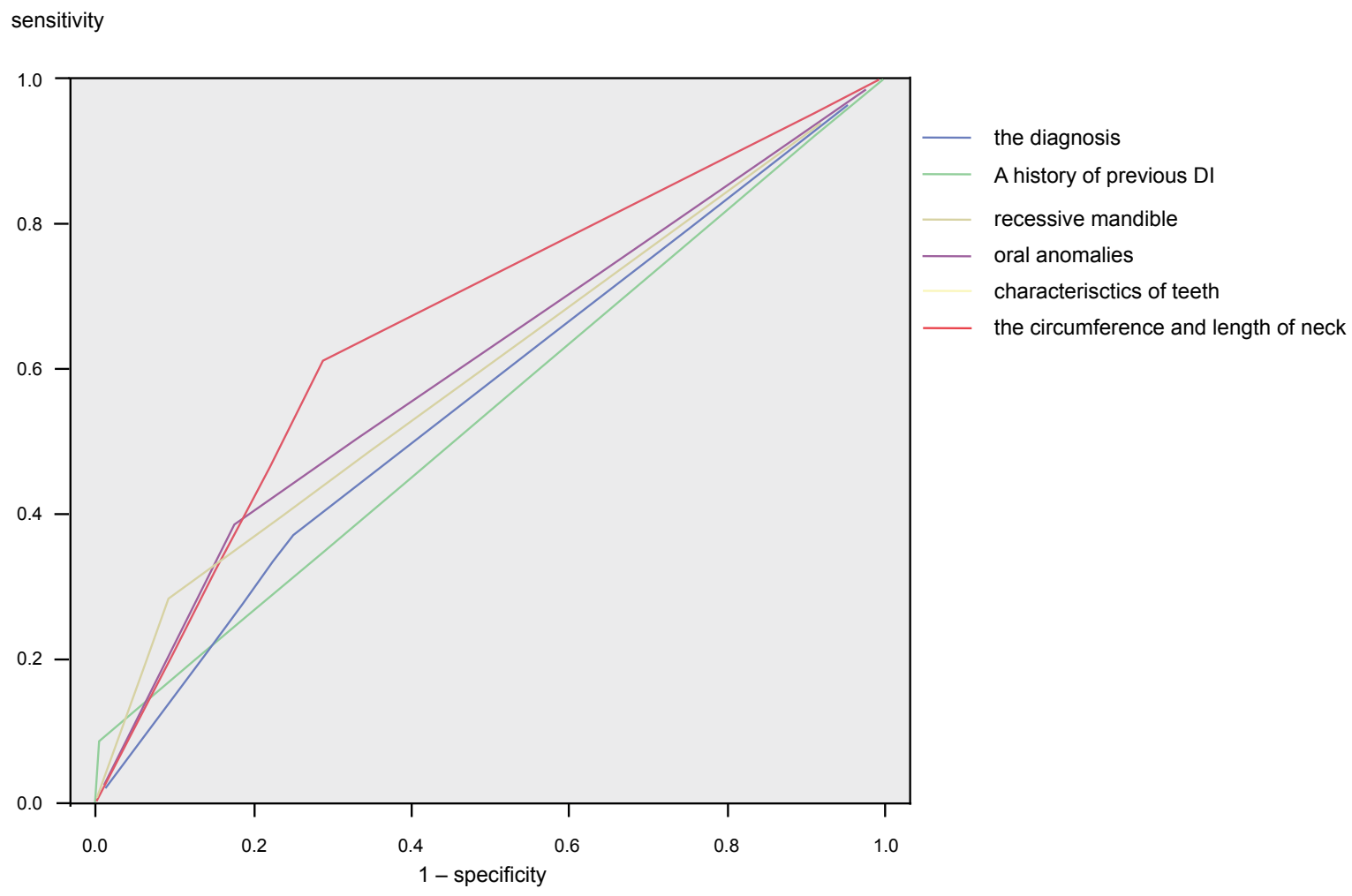

Fig. 1. Sensitivity and specificity of individual risk factors for difficult intubation (DI).

surgery of $16.5 \%{ }^{7}$. Given that the incidence of DI in other branches of surgery in patients with no anatomic anomalies of the head and neck was about $1 \%$ in most

Table 5. Intubation techniques applied in patients with difficult intubation

\begin{tabular}{l|l|c}
\hline \multicolumn{2}{c|}{} & $\begin{array}{c}\text { Number (\%) } \\
\text { of patients }\end{array}$ \\
\hline \multirow{4}{*}{$\begin{array}{l}\text { Number of } \\
\text { attempts to } \\
\text { intubate }\end{array}$} & Once & $37(22.8 \%)$ \\
\cline { 2 - 3 } & Once with pressure & $23(14.2 \%)$ \\
\cline { 2 - 3 } & $\begin{array}{l}\text { Twree times with pressure } \\
\text { pressure }\end{array}$ & $64(39.5 \%)$ \\
\hline $\begin{array}{l}\text { More than three times } \\
\text { with pressure }\end{array}$ & $30(18.5 \%)$ \\
\hline \multirow{2}{*}{$\begin{array}{l}\text { Duration of } \\
\text { intubation }\end{array}$} & Standard & $8(4.9 \%)$ \\
\cline { 2 - 3 } & Prolonged & $30(18.5 \%)$ \\
\cline { 2 - 3 } $\begin{array}{l}\text { Method of } \\
\text { intubation }\end{array}$ & $\begin{array}{l}\text { Longer than 10 minutes } \\
\text { Macing standard }\end{array}$ & $38(60.5 \%)$ \\
\cline { 2 - 3 } & Fiberoptic & $122(75.3 \%)$ \\
\hline
\end{tabular}

studies $^{12,13}$, it is clear that the risk of DI in thyroid surgery is several times higher than in other subpopulations of patients. On the other hand, the wide range of the incidence of DI in thyroid surgery (from 5.3\% to $16.5 \%$ ) can be explained by different definitions of DI, but also there is an important question how many anesthesiologists were included in these studies and how experienced they were, which was not clearly defined in most studies. In our previous study, all 2000 patients were intubated by two experienced anesthesiologists, and in the second study more anesthesiologists were involved, including younger anesthesia residents, which may explain the higher incidence of DI in the second study.

Our study showed DI to be more common in older patients, although age was not an independent risk factor. This is consistent with the results reported by Loftus et al., who showed that older age was a risk factor for $\mathrm{DI}^{14}$. It is assumed that poor dentition and osteoarthritic changes, often seen in this subpopulation of patients, may be a contributing risk factor for DI. 
Although both study groups included more females, DI was significantly more prevalent in men, which is consistent with the results of our previous study $^{10}$. Results reported by Bouaggad et al. ${ }^{5}$ are in accordance with our results. However, some studies have shown that the incidence of DI is higher in women $^{6}$, while others showed the incidence of DI to be similar in both genders ${ }^{7}$.

Dislocation and/or stenosis of the trachea were significantly more present in the group with DI in our study. This is the reason why in our Center, an $\mathrm{x}^{-}$ ray is required prior to thyroid surgery. Some studies dispute the importance of dislocation of the trachea as a risk factor for DI in thyroid surgery. In the study by Hong et al., it was shown that the incidence of DI was $7 \%$ in patients with tracheal deviation and $5 \%$ in patients without tracheal deviation, which was not statistically significantly different, and the authors concluded that preoperative $\mathrm{x}$-ray was not necessary ${ }^{15}$.

Our study showed that one of the independent predictors of DI is surgical diagnosis, i.e. thyroid gland disease (with a sensitivity of $37 \%$ ). The analysis of primary diagnosis in the group of patients with DI showed that the highest number of DI were present in the group of patients with multinodular goiter, followed by the group with hyperthyroidism and those with cancers, and the least in the group with nodular goiter. Since patients with multinodular goiters, as a rule, have maximum dimension of goiter, and those with nodular goiters the least thyroid size, this indirectly proves that the size of goiter has the largest share in DI occurrence, as shown by the results of a recent study by Agarwal et al. ${ }^{16}$.

The circumference and length of the neck in our study were singled out as one of the most important risk factors for DI and as an independent predictor of DI in thyroid surgery. The highest sensitivity was observed precisely with this test, while the specificity of this test was (not surprisingly) the lowest. This test was expected to be one of the most powerful predictors of DI in this branch of surgery, since extremely enlarged thyroid gland (which also leads to dislocation of the larynx and/or trachea) certainly contributes to the high neck circumference. Similar results have also been reported by other authors; among all risk factors that were evaluated in the study by Khan et al., neck circumference and Mallampati score greater than 3 were the most important predictors of difficult intubation ${ }^{17}$. Studies by Lacoste et al. ${ }^{18}$ and Voyagis et al. ${ }^{19}$ also demonstrated that a large neck circumference (as a result of thyromegaly) significantly influenced the occurrence of DI in thyroid surgery. Increased neck circumference, whether as a result of thyromegaly, obesity or other reasons, causes DI as an independent risk factor or associated with other factors, as shown by numerous reports ${ }^{20,21}$. Furthermore, it has been found that circumference of the neck has a predictive value even in lean patients ${ }^{22}$.

A history of previous DI was an independent risk factor for DI in our study and had the highest specificity of $95 \%$. The study by De Jong et al. demonstrated a significant relationship between the history of previous DI and the occurrence of $\mathrm{DI}^{23}$. Lundstrøm's study supports the fact that previous DI represents a significant risk factor for DI, but the author did not show that it was an independent predictor of $\mathrm{DI}^{24}$, as it was the case in our study.

Recessive mandible in our study was also an independent predictor of DI. Bouaggad et al. in the study conducted on 320 patients observed no statistically significant difference in the prevalence of patients with recessive mandible between the groups with and without $\mathrm{DI}^{5}$. However, recessive mandible in that study was noted in only $3.4 \%$ of the total number of patients, while in our study recessive mandible was present in $10.5 \%$ of patients. In addition, Bouaggad et al. ${ }^{5}$ excluded patients with anomalies of the upper airways and for defining DI, they used the Intubation Difficulty Scale, which minimally takes into account the characteristics of patients. These differences may be the reasons for different results of our study and those by these authors.

Patients with long and asymmetric teeth were significantly more present in the group with DI. Tooth characteristics were also an independent risk factor for DI in our study. Results of the prospective study conducted by Eberhart et al. ${ }^{25}$ showed a statistically significant association between the existence of protruding front teeth of the upper jaw, Mallampati score and the possibility of mouth opening with the occurrence of DI. The authors demonstrated the significance of the examined parameters individually and their combination in predicting DI. Dentition 
abnormalities have been shown to pose a significant risk factor for $\mathrm{DI}^{26}$.

Oral anomalies exerted significant influence on the incidence of DI in our study. Macroglossia was identified as an independent risk factor in other studies as well ${ }^{27}$.

Many studies indicate the necessity of additional equipment besides the standard Macintosh laryngoscope, primarily fiber optic bronchoscope in order to resolve a problematic airway ${ }^{28-30}$.

In all patients, including those who had a very high-risk score and where it was almost certain that DI would occur, we primarily tried to intubate in a conventional manner, using Macintosh laryngoscope. The inability of glottis visualization and of intubation in 1-3 attempts was considered as impossible intubation, and then we intubated using fiber optic bronchoscope. This scenario occurred in nearly $25 \%$ of DI cases. Although Maldini et al. ${ }^{31}$ presented advantages of the Bonfils Retromolar Fiberscope usage in the cases of anticipated difficult airway, we had no possibility of this device application in our Institution. The incidence of impossible tracheal intubation varies from 1 to 2000 cases in elective surgery, more than 1 in 250 in obstetrics, and up to $1 \%$ in emergency states ${ }^{32,33}$.

\section{Conclusion}

Dislocation and/or tracheal stenosis represent a significant risk factor for DI, not individually, but in combination with other factors. Evaluation of the airway prior to thyroid surgery should include a larger number of examinations including preoperative $\mathrm{x}$ ray of the neck and chest. Our study found that the strongest predictors of DI were history of previous DI, thyroid gland disease, size of the neck (circumference and length), recessive (retrognathic) mandible, teeth (irregular, large) and oral anomalies (small mouth, macroglossia).

\section{Acknowledgment}

This work was supported by the Ministry of Education, Science and Technological Development of the Republic of Serbia (grant No. 175 042: Epidemiological investigations of risk factors for selected health disorders).

\section{References}

1. Barash PG, Cullen BF, Stoelting RK. Airway management. In: Barash PG, Cullen BF, Stoelting RK, editors. Clinical Anesthesia,. $5^{\text {th }}$ ed. United States: Lippincott Williams \& Wilkins; 2006; p.440-56.

2. Miller R. Evaluation of the airway. In: Miller RD, editor. Miller's Anesthesia, $6^{\text {th }}$ ed. Philadelphia: Churchill Livingstone; 2004. p. 1621-3.

3. Dy B, Wise K, Farley D, McGlinch B. Extreme tracheal compression due to substernal goiter: surgical and anesthetic management. World J Endocr Surg. 2012;4(2):71-3.

4. Piao M, Yuan Y, Wang Y, Feng C. Successful management of trachea stenosis with massive substernal goiter via tracheobronchial stent. J Cardiothorac Surg. 2013;15(8):212. doi: 10.1186/1749-8090-8-212.

5. Bouaggad A, Nejmi SE, Bouderka MA. Prediction of difficult tracheal intubation in thyroid surgery. Anaesth Analg. 2004;99:603-6.

6. Amathieu R, Smail N, Catineau J, Poloujadoff MP, Samii K, Adnet F. Difficult intubation in thyroid surgery: myth or reality? Anesth Analg. 2006;103:965-8.

7. Shah PN, Gupta G. Prediction of difficult endotracheal intubation in thyroid surgery. Int J Anesth Res. 2014;2(1):6-10.

8. Cormack RS, Lehane J. Difficult tracheal intubation in obstetrics. Anaesthesia. 1984;39(11):1105-11.

9. A report by the American Society of Anesthesiologists Task Force on Management of the Difficult Airway. Practice guidelines for management of the difficult airway. Anesthesiology. 1993;78(3):597-602.

10. Kalezić N, Milosavljević R, Paunović I, Živaljević V, Diklić A, Matić D, et al. The incidence of difficult intubation in 2000 patients undergoing thyroid surgery: single center experience. Vojnosanit Pregl. 2009;66(5):377-82.

11. Adnet F, Borron SW, Racine SX, Clemessy JL, Fournier JL, Plaisance $\mathrm{P}$, et al. The intubation difficulty scale (IDS): proposal and evaluation of a new score characterizing the complexity of endotracheal intubation. Anesthesiology. 1997;87;1290-7.

12. Yentis SM, Hirsch NP, James K. Anaesthesia and intensive care AZ: an encyclopaedia of principles and practice. Elsevier Health Sciences. 2013; p. 324.

13. Savva B. Prediction of difficult tracheal intubation. Br J Anaesth. 1994;73:149-53.

14. Loftus PA, Ow TJ, Siegel B, Tassler AB, Smith RV, Schiff BA. Risk factors for perioperative airway difficulty and evaluation of intubation approaches among patients with benign goiter. Ann Otol Rhinol Laryngol. 2014;123(4):279-85. doi: $10.1177 / 0003489414524171$.

15. Hong BW, Mazeh H, Chen H, Sippel R. Routine chest x-ray prior to thyroid surgery: is it always necessary? World J Surg. 2012;36(11):2584-9. doi: 10.1007/s00268-012-1720-z 
16. Agarwal A, Agarwal S, Tewari P, Gupta S, Chand G, Mishra A, et al. Clinicopathological profile, airway management, and outcome in huge multinodular goiters: an institutional experience from an endemic goiter region. World J Surg. 2012;36.4:755-60. doi: 10.1007/s00268-012-1447-x.

17. Khan MN, Rabbani MZ, Qureshi R, Zubair M, Zafar MJ. The predictors of difficult tracheal intubations in patients undergoing thyroid surgery for euthyroid goitre. J Pak Med Assoc. 2010;60(9):736-8.

18. Lacoste L, Montaz N, Bernit AF, Gineste D, Lehuede MS, Barbier J, et al. Airway complications in thyroid surgery. Ann Otol Rhinol Laryngol. 1993;102(6):441-6.

19. Voyagis GS, Kyriakos KP. The effect of goiter on endotracheal intubation. Anesth Analg. 1997;84(3):611-2.

20. Brodsky JB, Lemmens HJ, Brock-Utne JG, Vierera M, Saidman LJ. Morbid obesity and tracheal intubation. Anesth Analg. 2002;94:732-6.

21. Kim WH, Ahn HJ, Lee CJ, Shin BS, Ko JS, Choi SJ, et al. Neck circumference to thyromental distance ratio: a new predictor of difficult intubation in obese patients. Br J Anaesth. 2011;106(5):743-8. doi: 10.1093/bja/aer024.

22. Gonzalez H, Minville V, Delanoue K, Mazerolles M, Concina $\mathrm{D}$, Foucade $\mathrm{O}$. The importance of increased neck circumference to intubation difficulties in obese patients. Anesth Analg. 2008;106:1132-6. doi: 10.1213/ane.0b013e3181679659.

23. De Jong A, Molinari N, Terzi N, Mongardon N, Arnal JM, Guitton $\mathrm{C}$, et al. Early identification of patients at risk for difficult intubation in the intensive care unit: development and validation of the MACOCHA score in a multicenter cohort study. Am J Respir Crit Care Med. 2013;187(8):832-9. doi: 10.1164/rccm.201210-1851OC.

24. Lundstrøm LH. Detection of risk factors for difficult tracheal intubation. Dan Med J. 2012;59(4):B4431.
25. Eberhart LHJ, Arndt C, Aust HJ, Kranke P, Zoremba M, Morin A. A simplified risk score to predict difficult intubation: development and prospective evaluation in $3763 \mathrm{pa}-$ tients. Eur J Anaesthesiol. 2010;27(11):935-40. doi: 10.1097/ EJA.0b013e328338883c.

26. Naithani U, Gupta G, Gupta GM, Meena K, Sharma CP, Bajaj P. Predicting difficult intubation in surgical patients scheduled for general anaesthesia: a prospective study of 435 patients. JEMDS. 2013;2(14):2270-86.

27. Shah PN, Sundaram V. Incidence and predictors of difficult mask ventilation and intubation. Anaesthesiol Clin Pharmacol. 2012;28(4):451-5. doi: 10.4103/0970-9185.101901.

28. Mazères JE, Lefranc A, Cropet C, Steghens A, Bachmann P, Perol $\mathrm{O}$, et al. Evaluation of the Bonfils intubating fiberscope for predicted difficult intubation in awake patients with ear, nose and throat cancer. Eur J Anaesthesiol. 2011;28:646-50. doi: 10.1097/EJA.0b013e3283495b85.

29. Kovacs G, Law J. A, Petrie D. Awake fiberoptic intubation using an optical stylet in an anticipated difficult airway. Ann Emerg Med. 2007;49:81-3.

30. Kim SH, Woo SJ, Kim JH. A comparison of Bonfils intubation fiberscopy and fiberoptic bronchoscopy in difficult airways assisted with direct laryngoscopy in difficult airways assisted with direct laryngoscopy. A comparison. Korean J Anesthesiol. 2010;58:249-55. doi: 10.4097/kjae.2010.58.3.249.

31. Maldini B, Goranović T, Vučić M, Kovač J, Baranović S, Letica-Brnadić R. Difficult airway management at Sestre milosrdnice University Hospital Center. Acta Clin Croat. 2012;51:473-6.

32. Cook TM, MacDougall-Davis SR. Complications and failure of airway management. Br J Anaesth. 2012;109(1):68-85. doi: 10.1093/bja/aes393.

33. Bokhari A, Benham SW, Popat MT. Management of unanticipated difficult intubation: survey of current practice in the Oxford region. Eur J Anaesth. 2004;21:123-7. 
Sažetak

\title{
PREDIKTORI ZBRINJAVANJA OTEŽANOG DIŠNOG PUTA U KIRURGIJI ŠTITNJAČE: PETOGODIŠNJA OPSERVACIJSKA PROSPEKTIVNA STUDIJA U JEDNOM CENTRU
}

\author{
N. Kalezic, V. Sabljak, K. Stevanović, B. Miličic, D. Marković, A. Tošković, M. Stojanović i V. Živaljević
}

Otežana intubacija (OI) traheje je češća u kirurgiji štitnjače nego u drugim kirurškim granama zbog tireomegalije. Pravilna prijeoperacijska evaluacija dišnoga puta je neophodna za smanjenje brojnih potencijalnih komplikacija. Ispitivali smo učestalost OI u kirurgiji štitnjače, utjecaj dislokacije traheje i drugih čimbenika na OI. Provedena je prospektivna studija na 2379 bolesnika podvrgnutih operacijama štitne žlijezde u Centru za endokrinu kirurgiju Kliničkog centra Srbije u Beogradu u razdoblju od 2007. do 2012. godine. Bolesnici su bili podijeljeni u skupine s OI ( $n=162$ ) i bez OI ( $n=2217$ ). Uz dislokaciju i/ili stenozu traheje definirano je još 13 čimbenika rizika sadržanih u 13 probirnih testova i 3 dodatna čimbenika - spol, životna dob i dijagnoza. Učestalost OI u našoj studiji iznosila je 6,81\%. Prisutnost dislokacije traheje bila je statistički značajan, ali ne i nezavisni prediktor OI. Kao najznačajniji i nezavisni prediktori OI izdvojili su se: dijagnoza, veliki obim i mala dužina vrata, prethodna OI, recesivna mandibula, karakteristike zuba i oralne anomalije. Najveću osjetljivost imali su obim i dužina vrata, a najveću specifičnost prethodna OI. Ako dovodi do dislokacije i/ili stenoze traheje, tireomegalija je značajan prediktor OI, ne samostalno, nego u kombinaciji s drugim čimbenicima.

Ključne riječi: Dišni put, zbrinjavanje; Intubacija, intratrahealna; Tireoidne bolesti - kirurgija; Dislokacija traheje 